\title{
STAN BIBLIOTEK I ZBIORÓW ARCHIWALNYCH BAZYLIAŃSKICH KLASZTORÓW W ŚWIETLE WIZYTACJI (1799-1824)
}

\section{Streszczenie}

Do podstawowych źródeł w badaniach nad książnicami klasztornymi obok katalogów bibliotecznych należą akta wizytacyjne, rejestrujące liczebność wspólnot, zabudowania klasztorne, podstawy finansowe jak i wielkość księgozbiorów monasterskich. Wizytatorzy odnotowywali liczbę tomów, zawartość treściową, pomieszczenia bibliotek jak i przechowywaną dokumentację archiwalną poszczególnych placówek zakonnych. Zachowane wizytacje monasterów bazyliańskich pozwalają na analizę 27 księgozbiorów na terenie unickiej diecezji łuckiej w ciągu pierwszego ćwierćwiecza XIX wieku. Dokumentacja ta umożliwia ustalenie liczebności zbiorów, tempa ich przyrostu, zakresu tematycznego. Kilkanaście lat później, po kasacie bazylianów, większość tych bibliotek została rozproszona, spora część książek przekazana placówkom oświatowym a cenniejsze egzemplarze do muzeów i bibliotek uniwersyteckich. Akta wizytacyjne stanowią więc cenne źródło do rozpoznania zbiorów, miejsc w których były przechowywane, a także zawartości archiwów klasztornych. Gromadzono w klasztorach zarówno dzieła teologiczne, jak i literaturę piękną, manuskrypty i wydania zachodnioeuropejskie. Zasięg polskich i zagranicznych typografii świadczył o wysokiej kulturze intelektualnej zakonu. Książnice stanowiły przede wszystkim wsparcie w pracy duszpasterskiej i oświatowej zakonników. Bibliotekizakonnebyłyzróżnicowanepodwzględemwielkości, organizacjiiwartości merytorycznej, ale nawet niewielkie wspólnoty rozproszone w wiejskich ośrodkach dawały możliwość obcowania z książką i kształcenia dla miejscowej młodzieży. Niewątpliwie tworzyły one pejzaż kulturowy tych ziem.

Słowa kluczowe: biblioteki; akta wizytacyjne; archiwa klasztorne; bazylianie; unicka diecezja łucka; Kościół greckokatolicki

* Irena Wodzianowska - dr hab. historii, adiunkt w Instytucie Historii, Katolicki Uniwersytet Lubelski Jana Pawła II

e-mail: irena.wodzianowska@kul.pl

https://orcid.org/0000-0001-5058-8015 
$* * * * *$

Na ziemiach Rzeczypospolitej Obojga Narodów w 1773 r. istniało 147 męskich monasterów bazyliańskich (1258 zakonników). Po kolejnych rozbiorach znalazło się na terenie imperium rosyjskiego 98 placówek. W powołanej w $1797 \mathrm{r}$. przez Pawła I unickiej diecezji łuckiej, obejmującej gubernię kijowską, podolską i wołyńską, pozostało już tylko 30 monasterów. W pierwszej fali kasat (17951796) zamknięto bowiem 11 z 41 klasztorów ${ }^{1}$. W dalszej kolejności zlikwidowano jeszcze kilka głównie niewielkich wspólnot [Horodyszcze, Kołodeżno (1804), Niskienicze, Zimne (1807), Malejowce (1810) i Strakłów (1812)] oraz ograniczono prace wydawnicze i oświatowe.

W ciągu swego istnienia bazyliańskie klasztory były ośrodkami nauczania, gromadzenia ksiąg, drukowania, stąd ich biblioteki stanowiły jedne $\mathrm{z}$ najbogatszych zbiorów. Wyjątkowość książnic bazyliańskich polegała także na tym, że prezentowały one syntezę zachodniej i wschodniej tradycji. W rozpoznaniu tych zbiorów obok rozproszonych w instytucjach naukowych kilku krajów inwentarzy bibliotecznych pomocne stają się znacznie lepiej zachowane protokoły wizytacyjne. Akta wizytacji stanowią istotne źródło informacji o funkcjonowaniu monasterów bazyliańskich w granicach zaboru rosyjskiego. Są zapisem trudnego funkcjonowania tych placówek w imperium carów, w którym w wyniku antyunickiej polityki zakon stopniowo tracił autonomię, monastery, cerkwie, miejsca pątnicze, szkoły, drukarnie, fundusze, księgozbiory i archiwa.

Podstawą niniejszego opracowania o bibliotekach bazyliańskich są wizytacje klasztorne od końca XVIII wieku² do 1824 r. Były one przeprowadzane właściwie co kilka lat przez delegatów biskupa lub władz zakonnych. Zawierają informacje dotyczące zarówno zabudowań klasztornych, jak i świątyń, majątku ruchomego, zapisów funduszowych oraz kapitałowych. Uwzględniono tu także działalność zakonników - duszpasterską (wykaz parafii, liczba wiernych), oświatową (prowadzone szkoły świeckie, jak i zakonne, liczba uczniów) oraz charytatywną (szpitale, przytułki itp.). Zbiory wizytacji przechowywane są w kilku instytucjach ukraiń-

${ }^{1}$ Zlikwidowano wówczas klasztory w Białołówce, Czetwertni, Granowie, Gródku, Hołowczyńcach, Kamieńcu Podolskim, Korżowcach, Ostrogu, Satanowie, Szarogrodzie, Zahajcach. Zob. szerzej I. Wodzianowska, Etapy likwidacji wspólnot bazyliańskich w Imperium Rosyjskim na przykładzie Prawobrzeżnej Ukrainy, w: Kasaty klasztorów na obszarze dawnej Rzeczypospolitej Obojga Narodów i na Śląsku na tle procesów sekularyzacyjnych w Europie, red. M. Derwich, t. 1: Geneza. Kasaty na ziemiach zaborów austriackiego i rosyjskiego, Wrocław 2014, s. 272-273.

${ }^{2}$ Zasoby biblioteczne niektórych monasterów przed $1780 \mathrm{r}$. omawia B. Lorens, Bazylianie prowincji koronnej w latach 1743-1780, Rzeszów 2014, s. 393-406. 
skich i rosyjskich ${ }^{3}$. Analiza 27 bazyliańskich księgozbiorów klasztornych ${ }^{4} \mathrm{w}$ okresie 25 lat została uzupełniona o odnalezione katalogi biblioteczne.

Bazylianie rozwinęli działalności duszpasterską, oświatowo-wychowawczą, prowadząc parafie, misje ludowe oraz różnego typu szkoły (elementarne, średnie, zakonne), a także wydawniczą. Władze zakonu dbały o to, by klasztory posiadały księgozbiory. Analiza przepisów zakonnych pozwala na stwierdzenie, że kwestia bibliotek monasterskich była obecna na kapitułach zarówno w XVII, jak i XVIII wieku. Wypracowano szereg przepisów dotyczących funkcjonowania bibliotek i obowiązków bibliotekarzy, ostatecznie sformułowanych w konstytucjach zakonnych w 1776 r. $^{5}$ „Regulae bibliothecarii”. Składające się z 11 punktów powierzały wykształconemu mnichowi księgozbiór, dbanie i gromadzenie, określały sposób prowadzenia biblioteki, katalogu, zapis autora, tytułu, podział językowy, ale również sprzątanie i ścieranie kurzów, wietrzenie pomieszczenia raz $\mathrm{w}$ tygodniu.

Liczebność i wartość książnic poszczególnych placówek bazyliańskich zależała zarówno od zamożności klasztoru, liczby zakonników, ich wykształcenia, jak i działalności w lokalnych społecznościach. Należy zaznaczyć spore różnice w liczebności bibliotek. Analiza zbiorów 27 klasztorów pod koniec XVIII wieku pozwala odnotować na ogół od kilkunastu (Tumin) do ponad 700 pozycji (Poczajów, Włodzimierz). Pod koniec omawianego okresu ich wielkość sięgała nawet 3000. Najliczniejsze księgozbiory zgromadziły klasztory prowadzące szkoły powiatowe (m.in. Bar, Humań, Lubar, Owrucz) oraz studia zakonne (Poczajów i Zahorów). W wizytacjach na ogół nie występował podział na zbiory klasztorne i szkolne, bez względu, czy była to szkoła świecka, czy studium zakonne. Dopiero w 1823 r. zarejestrowano w wizytacjach Humania i Lubaru dwa wyodrębnione księgozbiory klasztorny i szkolny ${ }^{6}$ oraz studium zakonnego w Zahorowie ${ }^{7}$.

Bibliotekę klasztorną $\mathrm{w}$ aktach wizytacyjnych odnotowywano po opisach cerkwi i zabudowań klasztornych, stanu liczbowego zakonników, parafii i funduszy. Poprzedzał ją lakoniczny zapis o pomieszczeniach, w których się znajdowała. Księgozbiór przechowywano najczęściej w jednej z cel zakonnych,jak m.in. w Pod-

${ }^{3}$ Wizytacja z lat 1799-1820 objęła tylko klasztory: Białystok, Dermań, Dubno, Humań, Łuck, Malejowce, Niskiennicze, Poddębce, Strakłów, Tumin, Werchy, Zimne, Żydyczyn (Центральний державний історичний архів у Києві (dalej: ЦДІАУК), ф. 2227, оп. 1, спр. 508). Uzupełniają је zbiory Instytutu Rękopisów Narodowej Biblioteki Ukrainy, gdzie znajdują się kolejne wizytacje monasterów, m.in. w Kaniowie, Lisiance, Poczajowie, Strakłowie (Інститут рукопису Національної бібліотеки України ім. В. І. Вернадського (dalej: ІР НБУВ), ф. 231, № 152). Wizytacja z 1820 r. z Rosyjskiego Państwowego Historycznego Archiwum w Petersburgu uwzględnia wszystkie 23 wówczas istniejące monastery (Российский Государственный Исторический Архив (daleј: РГИА), ф. 797, оп. 6, д. 23104), oraz 16 z lat 1823-1824 (РГИА, ф. 824, оп. 2, д. 142).

${ }^{4}$ Nie udało się ustalić dla tego okresu liczebności księgozbiorów zakonnych w Horodyszczach, Kołodeżnie i Milczy.

${ }^{5}$ Zob. szerzej M. Pidlypczak-Majerowicz, Bazylianie w Koronie i na Litwie. Szkoły i książki w działalności zakonu, Warszawa 1986, s. 143-145.

${ }^{6}$ РГИА, ф. 824, оп. 2, д. 142, k. 110-155, 284-299v (zakonny), 157-165, 302-309 (szkolny).

${ }^{7}$ Tamże, k. 615-617. 
dębcach, Strakłowie czy Łucku․ W klasztorach prowadzących szkoły, jak w Białymstoku, Kaniowie, Lubarze czy Zahorowie ${ }^{9}$, były przeznaczone na ten cel osobne pomieszczenia. Największe sale biblioteczne najprawdopodobniej posiadały monastery w Barze, Humaniu, Krzemieńcu, Owruczu i Poczajowie. W Barze była to sala z dwoma oknami, cele zakonne posiadały tylko po jednym oknie. Można więc przypuszczać, że jej wielkość była również podwójna ${ }^{10}$. W Owruczu przeznaczono osobną salę $\mathrm{z}$ dwoma oknami, na drugim piętrze klasztoru, wyposażoną w szafy i regały, w których przechowywano zbiory biblioteczne i instrumenty dla gabinetów szkoły ${ }^{11}$. W Poczajowie także sala biblioteczna znajdowała się „nad stancyami dwoma", co może świadczyć o jej obszernych rozmiarach ${ }^{12}$. Prawdopodobnie dorównywały im wielkością humańska biblioteka o długości ponad 9,5 na prawie 6,5 metrów szerokości, o trzech oknach oraz sala biblioteczna w Krzemieńcu o podobnych wymiarach $(8,30 \times 6,56)$ z sześcioma oknami ${ }^{13}$.

Mniejsze zbiory książek w niewielkich liczbowo klasztorach przechowywano w rzadziej używanych pomieszczaniach. We Włodzimierzu chroniono księgi nad zakrystią „na sklepieniu” ${ }^{14}$, w Dubnie ponad 100 pozycji w szafie jednej z podwójnych $\operatorname{cel}^{15}$. W monasterach dorohobuskim i mieleckim księgozbiory mieściły się w rezydencjach opackich. Podobnie też w Werchach umieszczono bibliotekę w trzyizbowej „,sali starszeńskiej”" ${ }^{\text {. }}$. W niewielkim klasztorze w Niskieniczach nie było osobnej biblioteki, a księgi przechowywano w szafie u przełożonego, podobnie jak i w Puhynkach ${ }^{17}$. W opactwie żydyczyńskim księgozbiór złożono w skarbcu nad zakrystią wraz z archiwum klasztornym ${ }^{18}$. Podobnie w Lisiance, Milczy i Dermaniu, gdzie wraz z cerkiewnymi rzeczami ustawiono książki i archiwalia monasteru ${ }^{19}$.

Sale biblioteczne służyły również za czytelnie, więc w większości wyposażono je w szafy, regały, stoły i krzesła. We wszystkich zaś wspomnianych monasterach księgozbiory zakonne znajdowały się wraz ze szkolnymi. Wyodrębnienie w później-

${ }^{8}$ ЦДІАУК, ф. 2227, оп. 1, спр. 508, k. 103v; РГИА, ф. 824, оп. 2, д. 142, k. 187, 207; РГИА, ф. 797, оп. 6, д. 23104, k. 56. Brakuje zapisów o miejscu przechowywania książek w Dubnie, Tuminie, Malejowcach, Hoszczy, Tryhorach. Można przypuszczać, że tu również przeznaczono na zbiory osobną celę.

${ }^{9} \mathrm{~W}$ wizytacji z $1818 \mathrm{r}$. wspomina się o jeszcze niedokończonej sali nad refektarzem oraz pomieszczeniach dla biblioteki, garderoby i archiwum. ЦДІАУК, ф. 2070, оп. 1, спр. 104, k. 29v, 96.

${ }^{10}$ РГИА, ф. 797, оп. 6, д. 23104, k. 177.

${ }^{11}$ Zob. także B. Лось, Василіанські бібліотеки в світлі монастирських інвентарів Національної бібліотеки України ім. В.I. Вернадського (Правобережна Україна XVIII-XIX ст.), w: Między Rzymem a Nowosybirskiem. Księga jubileuszowa dedykowana ks. Marianowi Radwanowi SCJ, red. H. Łaszkiewicz, I. Wodzianowska, Lublin 2012, s. 608.

${ }^{12}$ IP НБУВ, ф. 231, № 152, k. 438v.

${ }^{13}$ РГИА, ф. 824, оп. 2, д. 142, k. 103, 225.

${ }^{14}$ РГИА, ф. 797, оп. 6, д. 23104, k. 65.

${ }^{15}$ РГИА, ф. 824, оп. 2, д. 142 , k. 86v.

${ }^{16}$ Nawet ten nieliczny zbiór zawierający 39 publikacji posiadał księgę rejestru biblioteki. РГИА, ф. 797, оп. 6, д. 23104, k. 84v.

${ }^{17}$ ІР НБУВ, ф. 231, № 152, k. 522.

${ }^{18}$ ЦДІАУК, ф. 2227, оп. 1, спр. 508, k. 160.

${ }^{19}$ РГИА, ф. 824, оп. 2, д. 142, k. 312v; ЦДІАУК, ф. 2227, оп. 1, спр. 508, k. 283. 
szym okresie szkolnych zbiorów pozwala domniemywać, że były one również przechowywane w osobnych regałach, gdyż powstały katalogi tychże bibliotek. Przy tworzeniu inwentarzy szkolnych nie zastosowano jedynego wzorca, gdyż spis książek biblioteki szkolnej w Humaniu zredagowano alfabetycznie, a w Lubarze tematycznie, uwzględniając też format książek ${ }^{20}$. Podobny podział tematyczny zastosowano chociażby w opisie biblioteki klasztornej w samym Lubarze i Kaniowie, wzbogacony o kolekcje dzieł ascetów, filozofów czy rozbudowany dział homiletyczny. Treściowo zaś zbiory klasztorne i szkolne znacznie się różniły. Księgozbiory placówek oświatowych zawierały głównie podręczniki, pomoce szkolne, słowniki, mapy i atlasy. W inwentarzu humańskim wyodrębniono 224 tytuły ${ }^{21}$ oraz 26 map, w lubarskim 648 tomów ${ }^{22}$. W bibliotekach tych również odnotowano największą liczbę egzemplarzy poszczególnych podręczników (od kilkunastu do 82). Ponadto w bibliotekach klasztorów prowadzących szkoły powiatowe obok szaf z książkami znajdowały się sztandary szkolne, okazy owadów, minerałów, kolekcje medalionów i numizmatów, globusy, camera obscura, cylindry, instrumenty matematyczne (cyrkiel, skale, kątomierze) i „machiny fizyczne” (barometry, termometry, mikroskopy $)^{23}$ czy muzealne osobliwości, np. w postaci mumii egipskiej ${ }^{24}$.

${ }^{20}$ Zawierał on działy: Pismo święte; katechizmy, żywoty i teologowie; kaznodzieje; książki do nabożeństwa; prawnicy; historycy, poetowie i retorowie; moraliści; matematycy; fizycy; gramatycy; słowniki; geografowie.

${ }^{21}$ РГИА, ф. 824, оп. 2, д. 142, k. 157-165.

${ }^{22}$ Tamże, k. 302-309.

${ }^{23} \mathrm{~W}$ aktach wizytacyjnych z lat 1820-1824 zawarto także opisy wyposażenia gabinetów: mineralnego, fizycznego, chemicznego, historii naturalnej czy matematycznego, np. w Humaniu - fizycznego, matematycznego, mineralnego, w Lubarze dodatkowo historii naturalnej i chemicznego, w Barze, Lubarze, Kaniowie i Owruczu - fizycznego i matematycznego.

${ }^{24} \mathrm{~W}$ zbiorach humańskich prezentowano ok. 1000 różnych minerałów, ponad 1700 medalionów i numizmatów. РГИА, ф. 824, оп. 2, д. 142, k. 103-103v. 


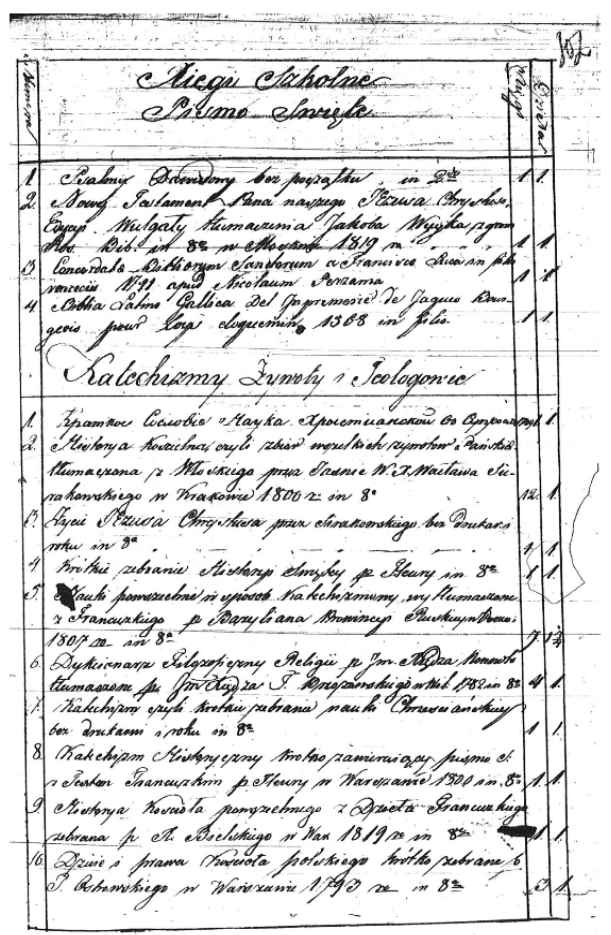

Il. 1. Fragment inwentarza biblioteki szkolnej w Lubarze z 1823 r. Źródło: РГИА, ф. 824, оп. 2, д. 142, k. 302.

Wizytatorzy przepisywali klasztorne zbiory biblioteczne, ale nie zalecali ich uzupełniania, lecz ,porządnieysze ksiąg ułożenie” w bibliotece, jak o. Leon Demkowicz w trakcie wizytacji monasteru w Poddębcach ${ }^{25}$, lub odnotowywali, że książki „w przyzwoitym porządku utrzymuią się" ${ }^{26}$ (Strakłów). Bezpośrednio księgozbiorem, jak przypuszcza M. Pidłypczak-Majerowicz, opiekował się bibliotekarz, czyli wyznaczony do tej funkcji któryś z zakonników, profesor studiów zakonnych lub przełożony klasztoru ${ }^{27}$. Na tym terenie większość monasterów zamieszkiwały niewielkie wspólnoty, stanowiące od 3 do 8 osób ${ }^{28}$. Natomiast w żadnym z opisów wizytacyjnych nie odnotowano przy zakonnikach sprawowanej funkcji bibliotekarza.

${ }^{25}$ ЦДІАУК, ф. 2227, оп. 1, спр. 508, k. 13.

${ }^{26}$ Tamże, k. 104.

${ }^{27}$ Pidłypczak-Majerowicz, Bazylianie w Koronie i na Litwie, s. 147. Nazwiska bibliotekarza częściej pojawiają się w katalogach zakonników bazyliańskich. Por. taż, Książka i biblioteka bazyliańska $w$ XVII-XVIII w. oraz wptyw kasat na stan ich zachowania i opracowania, „Hereditas Monasteriorum", 1 (2012) s. 93.

${ }^{28}$ Przykładowo w klasztorach w Poddębcach i Żydyczynie w latach 1799-1820 mieszkało od 5 do 6 zakonników, Niskieniczach 4-5. Na ogół obsada monasterów w XIX wieku zmniejszała się np. w Strakłowie z 7 do 2 (1799-1812), w Dermaniu z 8 do 4, w Zimnym z 8 do 3, Białostoku z 15 do 7. 
I chociaż władze zakonu dbały o zwiększenie księgozbiorów i nakazywały posiadanie oraz zakup ksiąg, to próżno szukać w aktach wizytacyjnych pozycji zakupów książek w wydatkach rocznych klasztorów, poza kilkoma wyjątkami. Barski klasztor w 1820 r. przeznaczył 39 rubli ,na dokupowanie Xiążek do Biblioteki i Jnstrumenta Fizyczne i Muzyczne"29. W Zahorowie w 1818 r. przeznaczono 30 zł na „oliwę, olej, korzenie, papier, książki” ${ }^{30}$. W Mielcu w opisie biblioteki zanotowano zakup diariusza do szkoły za 24 zł. $^{31}$ Powstaje więc pytanie, w jaki sposób gromadzono księgozbiór?

Prawie wszystkie biblioteki powstały na podstawie książnic wcześniejszych wspólnot prawosławnych. O tempie gromadzenia zbioru na przestrzeni stuleci może świadczyć Dermań, gdzie w 1571 r. znajdowało się 40 książek świeckich, a na początku XVII wieku już ok. 400. Obok cyrylickich rękopisów i druków ${ }^{32}$ znajdowały się tu tytuły w języku polskim, greckim, niemieckim, włoskim czy łacińskim $^{33}$. Tematyka gromadzonych książek była różnorodna: teologiczne pozycje, jak i statut litewski, poezje Owidiusza czy opisanie różnych kamieni, drzew i zwierzą $^{34}$. Potwierdzają to zapisy wizytatorów odnotowujące rękopiśmienne księgi staro-cerkiewno-słowiańskie oraz inkunabuły w Dorohobużu, Mielcu, Zahorowie czy Zimnym ${ }^{35}$.

Najliczniejsze pozostawały wspólnoty kształcące młodzież zakonną, jak Poczajów czy Zahorów, lub prowadzące szkoły średnie. Na podstawie wizytacji ЦДІАУК, ф. 2227, оп. 1, спр. 508.

${ }^{29}$ Dla porównania: składki coroczne na seminarium wileńskie i kontrybucje zakonne wynosiły 98,50 rb. РГИА, ф. 797, оп. 6, д. 23104, k. 184.

${ }^{30}$ ЦДІАУК, ф. 2070, оп. 1, спр. 104, k. 109.

${ }^{31}$ РГИА, ф. 797, оп. 6, д. 23104, k. 86v. W Krzemieńcu w wydatkach zanotowano opłatę dla nauczyciela rysunków topograficznych i na potrzeby uczących się zakonników - 41 rb 42 kop. Tamże, k. 61 .

${ }^{32}$ Zob. analizę cyrylickich ksiąg na terenie Galicji: I. Almes, Księgi cyrylickie w bibliotekach monasterów bazyliańskich eparchii lwowskiej XVIII w., „Latopisy Akademii Supraskiej”, 7 (2016) s. 209-216.

${ }^{33}$ U. Pawluczuk, Monaster Świętej Trójcy w Dermaniu w II Rzeczypospolitej, w: Między Odra a Uralem. Ksiega dedykowana Profesorowi Władysławowi A. Serczykowi, red. W. Wierzbieniec, Rzeszów 2010, s. 500.

${ }^{34}$ Н. И. Петров, Описание рукописных собраний, находящихся в городе Киеве, Москва 1896, s. 175; РГИА, ф. 797, оп. 6, д. 23104, k. 85 v-86.

${ }^{35}$ Część odnalezionych w Instytucie Rękopisów omawia W. Łoś: Василіанські бібліотеки в світлі монастирських інвентарів, s. 619; Lista rękopisów: taż, Рукописна спадщина монастирів Греко- та Римо-католицької иерков у фондах Інституту рукопису Національної бібліотеки України імені В. I. Вернадського, „Hereditas Monasteriorum”, 6 (2015) s. 241-244. 


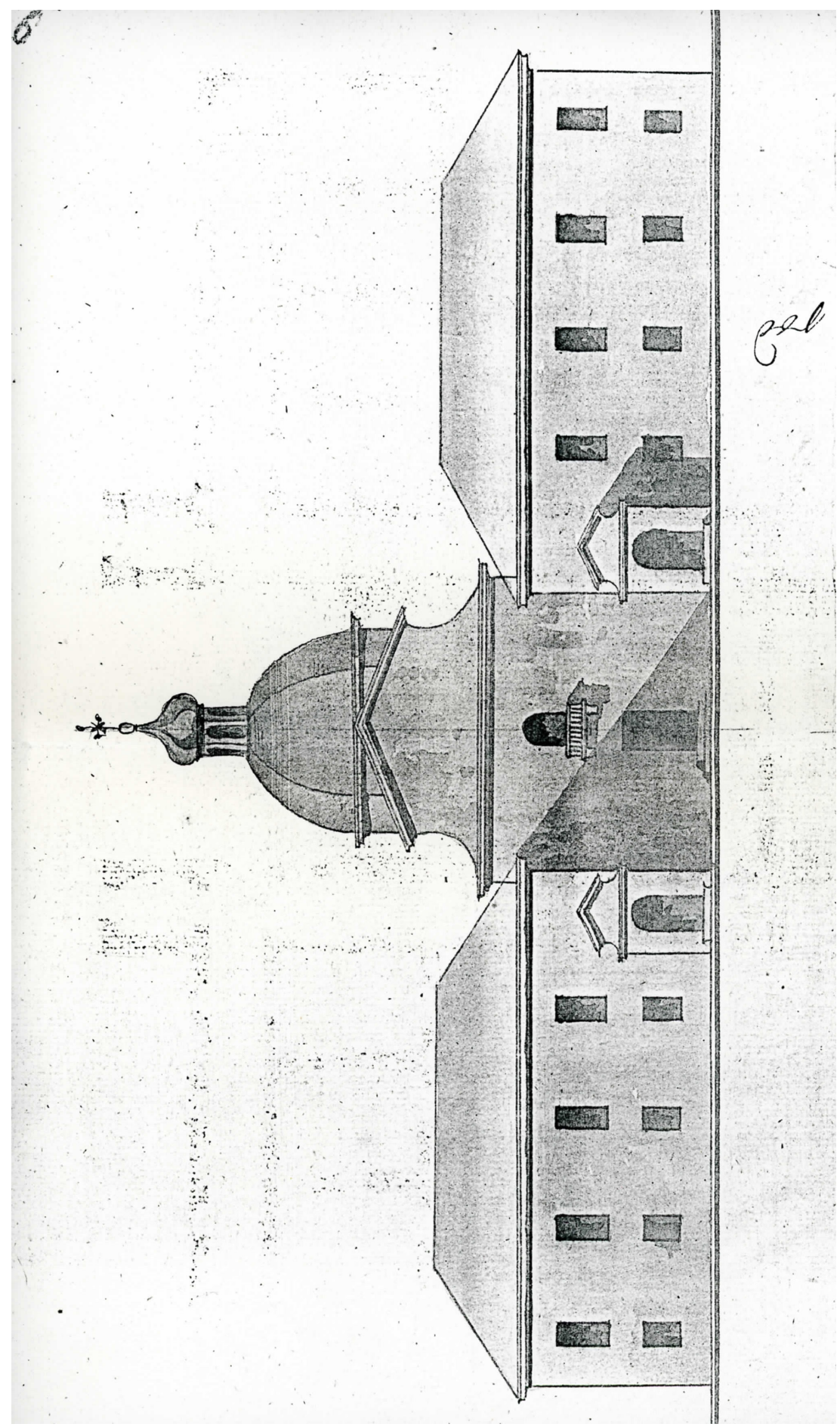

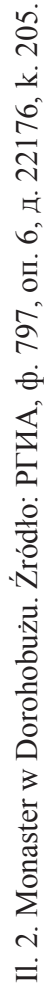


Nabywano także niezbędne pozycje do bibliotek, o czym świadczą zapisy w katalogach bibliotecznych. W XVIII wieku zasilały książnice klasztorne z pewnością także publikacje wydawane przez oficyny typograficzne bazylianów. Zakon posiadał bowiem sześć drukarni, a trzy największe z nich - Poczajów, Supraśl, Wilno, wydały w XVIII wieku w sumie 1420 druków ${ }^{36}$. Część pochodziła z prywatnych zbiorów bazylianów. Prywatne księgozbiory zakonników po ich śmierci włączano do książnicy klasztornej. Tłumaczyłoby to liczne pozycje włosko- czy niemieckojęzyczne w szczególności, gdy przejrzymy się wykształceniu zakonników mieszkających $w$ tych monasterach ${ }^{37}$. Tak według analizy inwentarza lubarskiego klasztoru dokonanego przez W. Loś $^{38}$ widzimy, że w 1777 r. biblioteka wzbogaciła się o 35 woluminów po śmierci o. Justyna Lubicza. Zakonnicy dokonywali także za życia darowizn na rzecz swych wspólnot. Tak wspomniany klasztor w Lubarze otrzymał w prezencie książki od o. Klemensa Wesołowskiego, m.in. podręczniki z geometrii i botaniki, czy o. Szaszkiewicza - z historii Kościoła po francusku ${ }^{39}$. Natomiast próżno szukać tego rodzaju informacji w protokołach wizytacyjnych. Głównym źródłem wiadomości pozostają katalogi biblioteczne i archiwalia zakonne. Przykładem może służyć inwentarz księgi zakupów owruckiego klasztoru z latach 1786-1789, przechowywany w Bibliotece Czartoryskich ${ }^{40}$.

W aktach wizytacyjnych natomiast tylko zapisy o księgozbiorze humańskim pozwalają na analizę liczby oraz zawartości publikacji nabywanych przez miejscowych zakonników. W opisie biblioteki klasztornej bowiem zaznaczono ,przybyłe" pozycje od ostatniej wizytacji. Zakupiono więc:

Pismo święte - 2, teologów 2, historycznych 90; prawników 23, medycznych

5 , geograficznych 5, filozoficznych, matematycznych i fizycznych 31 ; poetyc-

kich i retorycznych 183; gramatyk 5, wzorów do lekcji rysunków $30^{41}$.

Uwidacznia się tu prowadzona działalność oświatowa humańskich bazylianów, gdyż zakupów dokonano pod kątem pomocy dydaktycznych, a nie uzupełniania księgozbioru klasztornego.

${ }^{36}$ Por. Pidłypczak-Majerowicz, Książka i biblioteka bazyliańska w XVII-XVIII w. oraz wpływ kasat, s. 85-86.

${ }^{37}$ Por. także D. Wereda, Biblioteka bazylianów w Białej Podlaskiej, Archiwa, Biblioteki i Muzea Kościelne, 112 (2019) s. 427-430.

38 Лось, Василіанські бібліотеки в світлі монастирських інвентарів, s. 611. W Strakłowie w 1793 r. księgozbiór zwiększył się o 11 ksiąg po śmierci o. Antoniego Perefinowicza. Znacznie rzadziej książki stanowiły spłatę długu, jak w przypadku klasztoru tryhorskiego, gdy w 1818 r. Jan Gizdej oddał bibliotekę swojego brata w zamian za niespłacone zobowiązania. Zob. ЦДІАУК, ф. 2094, оп. 2, спр. 161.

${ }^{39}$ Inne darowizny na rzecz analizowanych monasterów zob. M. Pidłypczak-Majerowicz, Prywatne księgozbiory bazylianów prowincji koronnej zakonu na podstawie proweniencji wynotowanych z druków XVI-XVIII wieku w zbiorach Ossolineum. Zarys zagadnienia, „Z Badań nad Książką i Księgozbiorami Historycznymi”, 10 (2016) s. 103.

${ }^{40}$ Zob. szerzej: Pidłypczak-Majerowicz, Bazylianie w Koronie i na Litwie, s. 148.

${ }^{41}$ РГИА, ф. 797, оп. 6, д. 23104, k. 166. 
Tabela 1. Liczebność księgozbiorów klasztornych

\begin{tabular}{|c|c|c|c|c|}
\hline \multirow{2}{*}{ Lp. } & \multirow{2}{*}{ Miejscowość } & \multicolumn{3}{|c|}{ Liczba woluminów w poszczególnych latach } \\
\hline & & 1799 r. & $1820 r^{a}$ & $1824 \mathrm{r}$. \\
\hline 1 & 2 & 3 & 4 & 5 \\
\hline 1 & Bar & 226 & 1167 & 1711 \\
\hline 2 & Białystok & $281(1781)$ & 295 & 281 \\
\hline 3 & Dermań & 349 & $259^{\mathrm{b}}$ & - \\
\hline 4 & Dorohobuż & $?$ & $124^{c}$ & 89 \\
\hline 5 & Dubno & 4 & 135 & 115 \\
\hline 6 & Hoszcza & 286 & 119 & 131 \\
\hline 7 & Humań & $?$ & 1797 & 2853 \\
\hline 8 & Kaniów & $?$ & 948 & 986 \\
\hline 9 & Krzemieniec & $?$ & 1285 & 2220 \\
\hline 10 & Lisianka & $?$ & 205 & 109 \\
\hline 11 & Lubar & $223(1782)$ & 1386 & 1401 \\
\hline 12 & Luck & 255 & $?$ & 106 \\
\hline 13 & Malejowce & 142 & - & - \\
\hline 14 & Mielec & $240(1775)$ & 187 & 74 \\
\hline 15 & Niskienicze & 113 & - & - \\
\hline 16 & Owrucz & $?$ & 771 & $?$ \\
\hline 17 & Poczajów & 784 & 2507 & $?$ \\
\hline 18 & Poddębce $^{\mathrm{d}}$ & 243 & 182 & $?$ \\
\hline 19 & Puhynki & 143 & $132(1819)$ & 107 \\
\hline 20 & Strakłów & 42 & - & - \\
\hline 21 & Tryhory & $?$ & 410 & 384 \\
\hline
\end{tabular}

${ }^{a}$ Odnotowano w katalogach bibliotecznych również mapy: w Barze - 12, Humaniu - 25, Owru$\mathrm{czu}-36$.

${ }^{\mathrm{b}}$ J.M. Giżycki podaje inną liczbę księgozbioru - 302. Trudno stwierdzić, czy pochodziła ona z późniejszego okresu, gdyż dwa lata później klasztor został skasowany. (J.M. Giżycki, Spis klasztorów unickich bazylianów w województwie wolyńskiem, Kraków 1905, s. 16). Liczbę 259 tomów potwierdza katalog biblioteczny z 1821 r., odnaleziony przez W. Łoś w zbiorach Instytutu Rękopisów Narodowej Biblioteki Ukrainy (Лось, Василіанські бібліотеки в світлі монастирських інвентарів, s. 620).

c J.M. Giżycki podał, że klasztor wogóle nie posiadał biblioteki. Giżycki, Spis klasztorów, s. 19.

' ЦДІАУК, ф. 2227, оп. 1, спр. 508, k. 8, 14, 25 v. 


\begin{tabular}{|c|c|c|c|c|}
\hline $\mathbf{1}$ & $\mathbf{2}$ & $\mathbf{3}$ & $\mathbf{4}$ & $\mathbf{5}$ \\
\hline 22 & Tumin & 19 & 31 & $?$ \\
\hline 23 & Werchy & $?$ & 39 & 37 \\
\hline 24 & Włodzimierz & 765 & 763 & $?$ \\
\hline 25 & Zahorów & 500 & $541+300(1821)$ & $522^{6}$ \\
\hline 26 & Zimne & 27 & - & - \\
\hline 27 & Żydyczyn & Ponad 600 & 622 & $?$ \\
\hline
\end{tabular}

$?$ - nieznana liczba woluminów

Źródło: ЦДІАУК, ф. 2070, оп. 1, спр. 104; ф. 2227, оп. 1, спр. 508; РГИА, ф. 797, оп. 6, д. 23104; ф. 824, оп. 2, д. 142; ІР НБУВ, ф. 231, № 152; ф. I, № 3345, 3349; Лось, Василіанські бібліотеки в світлі монастирських інвентарів, s. 620.

Liczebność bibliotek w 1799 r. nie zawsze oddawała stan gromadzonych przez wieki książnic zakonnych. Po ostatnim rozbiorze część wspólnot bazyliańskich utraciła świątynie przyklasztorne, w których niejednokrotnie przechowywano książki. Biblioteka klasztoru w Dubnie na początku analizowanego okresu posiadała tylko cztery księgi ${ }^{4}$, gdyż rok wcześniej prawosławny protojerej powiatu dubieńskiego W. Bochanowski skonfiskował cały księgozbiór klasztorny. Podobny los spotkał bibliotekę w Hoszczy. Z akt wizytacyjnych z 1820 r. wynika, że kilkaset książek ze zbiorów monasterskich ulokowanych w zakrystii zostało po kryjomu wywiezionych do Ostroga po zajęciu klasztornej świątyni przez prawosławnego kapłana ${ }^{42}$. Wizytator więc po kilkunastu latach odnotował w spisie bibliotecznym tylko 119 książek, w tym już kilka dokupionych. Poza tym „wiele” zabrał prowincjał bazylianów o. Lewicki i do 1820 r. nie zwrócił monasterowi ${ }^{43}$. Kolejna wizytacja w 1824 r. odnotowała powolny wzrost liczebności biblioteki, wykazując 131 woluminów ${ }^{44}$. W Milczy natomiast, po tym jak wraz z cerkwią odebrano księgozbiór ułożony $\mathrm{w}$ skarbcu klasztornym ${ }^{45}$, nie próbowano już nawet odbudować zbiorów, poza niezbędnymi księgami liturgicznymi.

Do zmniejszenia zasobów bibliotecznych przyczyniły się także pożary. W $1809 \mathrm{r}$. spaliła się owrucka biblioteka. Klasztor ten prowadził szkołę, więc w odbudowę książnicy zaangażowano wszystkie bazyliańskie ośrodki, które wysyłały dublety

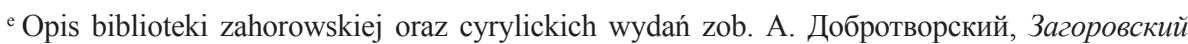
монастырь, его библиотека и сохранившийся в ней западно-русский литературный памятник XVII столетия, ЮЗ3Р, кн. 1, изд. 2, Киев 1863, s. 1-17; кн. 2, изд. 2, s. 75-115; кн. 3, изд. 2, s. $165-$ 196.

${ }^{42}$ Według J.M. Giżyckiego w 1816 r. „kazano im posłać bibliotekę własną do seminaryum dyzunickiego w Ostrogu" (Giżycki, Spis klasztorów, s. 35).

${ }^{43}$ ЦДІАУК, ф. 2227, оп. 1, спр. 508, k. 120.

${ }^{44}$ РГИА, ф. 824, оп. 1, д. 241, k. 92v. Książki jednak były w złym stanie technicznym „powiększey części są bez fort i tytułów".

${ }^{45}$ РГИА, ф. 797, оп. 6, д. 23104, k. 51. 
ze swoich zbiorów ${ }^{46}$. Nie wszystkie wspólnoty odnotowywały z radością te działania. W protokole wizytacyjnym klasztoru w Poddębcach w $1820 \mathrm{r}$. wpisano brak 61 ksiąg w porównaniu ze stanem z 1799 r., lakonicznie tłumacząc, że Pachomiusz Lewicki, opat owrucki, zabrał do Owrucza „kilkadziesiąt [książek] i rewersu na nie na groncie nie zostawił" ${ }^{\prime 7}$. Już w okresie urzędowania wspomnianego o. Lewickiego owrucka biblioteka zwiększyła się do 771 tomów. Niestety w wizytacjach poprzedzających pożar nie odnotowano liczebności księgozbioru, więc trudno jest wskazać, w jakim stopniu odtworzono zbiory ${ }^{48}$. Uzupełnianie książnic zniszczonych monasterów prawdopodobnie tłumaczy fakt, że księgozbiory niektórych wspólnot bazyliańskich, jak w Poddębcach, zmniejszyły się w porównaniu ze stanem sprzed 20 lat. W zbiorach łuckich tylko na przestrzeni czterech lat XIX wieku ubyło kilkadziesiąt ksiąg ${ }^{49}$.

Dbano przede wszystkim o księgozbiory monasterów prowadzących szkoły zakonne i świeckie. Powstaje więc pytanie, jak szybko były gromadzone na nowo biblioteki niewielkich wspólnot zakonnych. Tempo przyrostu liczbowego zbioru można zilustrować na przykładzie klasztoru w Tuminie. Po pożarze w lutym 1802 r. ocalało z monasterskiej biblioteki tylko 4 księgi ${ }^{50}$, natomiast już w wizytacjach 1819-1820 r. wymieniono 31 woluminów książnicy klasztornej oraz 28 liturgicznych ksiąg. Odbudowywany dubieński zbiór w 1820 r. wyniósł już 132 tomy. Najczęściej przybywało rocznie najwyżej kilka ksiąg jak w Niskieniczach $(121)^{51}$ czy Zimnym. Korzystając z zestawień katalogów bibliotecznych W. Łoś, można zauważyć, że w Białostoku w okresie od 1781 do 1820 r. zakupiono tylko 14 pozycji. Największe wzrosty liczebności bibliotek odnotowano jedynie w klasztorach zajmujących się działalnością oświatową. Przykładowo lubarski zbiór w 1782 r. wyniósł 223 tomy, a już w 1820 r. - 1386. W podobnym tempie wzrastała biblioteka zahorowskiego klasztoru, w którym odbywały się studia zakonne i działała szkoła parafialna. W 1781 r. było tu tylko 197 tomów ${ }^{52}$, w 1799 r. już 500, w 1804 r. - 515 oraz nieznany bliżej zbiór książek pochodzących prawdopodobnie ze skasowanych klasztorów. Nie włączono go do inwentarza bibliotecznego, a wielkość ówczesny wizytator ks. Antoni Buczyński ocenił na 500 pozycji53.

${ }^{46}$ Державний архів Житомирської області (dalej: ДАЖО), ф. 90, оп. 2, спр. 9, k. 21, 41-43v.

${ }^{47}$ РГИА, ф. 797, оп. 6, д. 23104, k. 12.

${ }^{48}$ Niewiele natomiast ucierpiały w 1818 r. w pożarze zbiory kaniowskie. Skrzętnie odnotowano tu 14 utraconych pozycji. Szkody zaś wyceniono na 222 rubli srebrem wraz ze zniszczonym wówczas częściowo wyposażeniem fizyko-matematycznego gabinetu. IP НБУВ, ф. II, № 3345, k. 4v.

${ }^{49}$ Przykładowo z działu Pisma świętego oraz ksiąg teologicznych -31 , ascetycznych -24 . Ale w niektórych, jak w filozoficznym, liczba ksiąg wzrosła z 55 do 66. Najliczniejszy księgozbiór odnotowano w wizytacji z 1804 r. - 226 pozycji. РГИА, ф. 823, оп. 3, д. 1282, k. 2-8.

${ }^{50}$ „Zostały tylko: Biblia ruska in folio; Nauki S Bazylego obyczaiowe ruskie in folio; Nauki Parochialne na Niedziele i święta całego Roku in 8to w dwóch tomach po rusku Polskiem drukiem; Textus Scripta S. Veteris de Novi Testamenti SS. Petr. Ac Varior”. ЦДІАУК, ф. 2227, оп. 1, спр. 508, k. 220v.

${ }^{51} \mathrm{~W}$ porównaniu ze stanem z 1799 r. zakupiono tu do 1804 r. osiem woluminów. ЦДІАУК, ф. 2227 , оп. 1 , спр. 508 , k. $330,359$.

${ }^{52}$ ЦДІАУК, ф. 2070, оп. 1, спр. 104, k. 7-9.

${ }^{53}$ Tamże, k. 44 v. 
W 1818 r. biblioteka klasztorna liczyła już 595 tomów, a kolejny wizytator o. Aleksander Sienicki odnotował ten sam stos spoczywających nieruchomo ksiąg, obliczając ich na ponad 500. W $1821 \mathrm{r}$. prowincjał o. Leon Demkowicz przepisał 541 ksiąg w inwentarzu oraz już tylko 300 ,niezarejestrowanych”, z czego wynikałoby, że rozpoczęto segregowanie, przekazując książki innym wspólnotom.

Wizytatorzy przepisywali książki, posługując się istniejącymi inwentarzami bibliotek, lustrując ich układ tematyczny na półkach szaf bibliotecznych. Zapis druku lub manuskryptu w aktach wizytacyjnych jest lakoniczny, a w każdym z nich powtarzają się wspólne elementy: autor, tytuł lub najczęściej fragment tytułu oraz liczba tomów, rzadziej format i adres wydawniczy. Odzwierciedlały natomiast kolekcje tematyczne księgozbiorów i sposób ich wyodrębnienia w poszczególnych klasztorach. Podział ksiąg w bibliotece na początku XIX wieku w większości analizowanych klasztorów był tematyczny, w odróżnieniu do poprzedniego stulecia, gdy najczęściej stosowano klasyfikację publikacji ze względu na format lub język, nie uwzględniając treści ${ }^{54}$. Tutaj uwidacznia się już stosowanie się w praktyce do rozporządzeń władz zakonnych, chociażby z 1776 r., nakazujących prowadzenie detalicznego katalogu książek ${ }^{55}$. Wyjątek stanowi tylko inwentarz biblioteki owruckiej, gdzie księgozbiór po pożarze został ponownie skatalogowany według alfabetu ${ }^{56}$. W części bibliotek obok podziału tematycznego zachował się również podział językowy, jak np. „książek ruskich” (Dermań, Łuck) lub szerzej jak w Zahorowie - „ksiąg słowiańskich różnych 46”. Podobnie w Malejowcach oprócz tematycznego spisu dodano działy „w języku włoskim (10), w języku niemieckim (6), w języku słowiańskim (10)". Także w katalogach większych księgozbiorów, jak w Humaniu, Owruczu, Poczajowie, Tryhorach, wyodrębniano pozycje obcojęzyczne. Tylko we Włodzimierzu odnotowano ogólnie - „książek w obcych językach 25”. Należy nadmienić, że w mniejszych zbiorach nie rejestrowano praktycznie książek w języku rosyjskim. Pojawiają się one w latach 20. w bibliotekach monasterów, prowadzących szkoły średnie. W Poczajowie według wizytacji z $1820 \mathrm{r}$. stanowiły one nadal niewielki odsetek -63 pozy$\mathrm{cje}^{57}$. W zbiorach humańskich $\mathrm{w}$ dziale mówców i poetów francuskich, włoskich, niemieckich i rosyjskich na 391 tytułów odnotowano tylko 14 rosyjskich. Ogółem biblioteki zawierały więcej rosyjskojęzycznych pozycji, gdyż szczątkowo znajdo-

${ }^{54}$ Por. Лось, Василіанські бібліотеки в світлі монастирських інвентарів, s. 613.

${ }^{55}$ Pidlypczak-Majerowicz, Bazylianie w Koronie i na Litwie, s. 151. Nie została skatalogowana w całości biblioteka klasztoru żydyczyńskiego. Zawierała ona w rzeczywistości więcej książek niż wykazano w wizytacji, gdyż składała się z ksiąg kilku poprzednich opatów, ,po których że sukcessorowie od dawna o sukcessyą nieukończyli z klasztorem prawności, zaczym jako rzecz kwestyonowana niezaciąga się w inwentarz".

56 „Xiąg znayduiących się polskich pod literą A 196; Xiąg łacińskich Klassycznych Historycznych pod Lit B 93; iąg Fizycznych pod Literą C 53; Xiąg Matematycznych pod Litrą D 26; Dykcyonarzów polskich i Łacińskich pod literą E 24; Xiąg Pisma S pod literą F 91; Xiążek Teologicznych pod literą G 60; Xiąg Kaznodzieyskich pod literą H 39; Xiążek w Języku Francuzkim pod literą J 96; Xiążek Rossyjskich pod literą K 67; Xiąg Niemieckich pod literą L 25; Jedna Xiążka w Języku Tatarskim pod literą R 1” РГИА, ф. 797, оп. 6, д. 23104, k. 140 v.

${ }^{57}$ IP НБУВ, ф. 231, № 152, k. 439v. 
wały się one we wszystkich działach tematycznych. Ich liczba bez wątpienia zwiększała się w zbiorach szkolnych.

Gdy chodzi o miejsce wydań publikacji pochodzących ze zbiorów bazyliańskich, to pomocne tu pozostają katalogi biblioteczne. Na podstawie inwentarza klasztoru tryhorskiego z 1828 r. można stwierdzić pochodzenie książek najczęściej z wydawnictw miast Berdyczowa, Wilna, Lwowa, Krakowa, Warszawy, Lublina, Poznania, Sandomierza (114), a dopiero na drugim miejscu poczajowskiej drukarni $(40)^{58}$. Poza tym biblioteka zawierała po kilka książek wydanych w Kijowie, Barcelonie, Wenecji, Rzymie, Antwerpii ${ }^{59}$. Katalog włodzimierskiej biblioteki z 1816 r. wskazuje przewagę druków z Warszawy (32), Wenecji (28), Rzymu (20), Wilna (19). Po kilka pozycji pochodziło zaś z oficyn wydawniczych Amsterdamu, Bassano del Grappa, Bazylei, Bolonii, Frankfurtu, Genewy, Heidelbergu, Florencji, Krakowa, Lipska, Lyonu, Mediolanu, Neapolu, Padwy, Paryża, Petersburga, Poitiers, Ratyzbony, Roterdamu, Wiednia, Wrocławia ${ }^{60}$. Najstarsze odnotowane książki wydrukowane zostały w XVI wieku (28), a liczba ksiąg wydawanych w kolejnych stuleciach wzrastała - 39 (XVII), 99 (XVIII) ${ }^{61}$ i 31 (w pierwszych 20 latach XIX stulecia) ${ }^{62}$. W zahorowskiej bibliotece odnotowano mniej inkunabułów (12), 49 druków pochodzących z XVII wieku, gros książek stanowiły zaś wydane w XVIII (243) i na początku XIX wieku $(200)^{63}$. Typografie Berdyczowa, Warszawy, Wilna, Lwowa, Krzemieńca i Wenecji (186) ogółem dominowały nad publikacjami poczajowskimi (70). Odmienny obraz można zaobserwować, analizując barską książnicę. Większość pozycji pochodziła tu z Warszawy (205), Wenecji (133) i Krakowa (123). Po ok. 100 egzemplarzy było wydanych we Lwowie, Petersburgu czy Wilnie i tylko 71 pozycji w Poczajowie, po kilkanaście pochodziło z in-

${ }^{58}$ Częściowy katalog poczajowskiej drukarni w: Каталог видань Почаївського та Унівського монастирів XVIII-XX cm. з колекиії Музею книги і друкарства України, упоряд. В.Г. Бочковська, Л.В. Хауха, В.А. Адамович, Київ 2008. Analizę druków rusko- i polskojęzycznych drukarni bazyliańskich zob. szerzej: J. Getka, Polskojęzyczne druki bazyliańskie (XVIII wiek), Warszawa 2013; taż, U progu modernizacji. Ruskojęzyczne drukarstwo bazyliańskie XVIII wieku, Warszawa-Lublin 2019.

${ }_{59}$ Obliczenia na podstawie: ЦДІАУК, ф. 2094, оп. 2, спр. 252.

${ }^{60}$ Szeroki zakres pozycji wydawanych w oficynach zagranicznych potwierdzają również badania poszczególnych księgozbiorów, m.in. w Białej: Wereda, Biblioteka bazylianów w Białej Podlaskiej, s. 430.

${ }^{61}$ Ukraińscy badacze przedstawiają odnalezione starodruki m.in. w Archiwum Obwodu Tarnopolskiego (I. Альмес, Латино- і польськомовні стародруки монастирського походження у фондах Державного архіву Тернопільської області, „Архіви України”, (2015) № 4 (297), s. 116126) czy wołyńskich instytucjach muzealnych (Стародруки Речі Посполитої XVII-XVIII cm.cm. у зібраннях Музею книги та друкарства м. Острога і Волинського краєзнавчого музею. Каталог, уклад. О.Л. Позіховський, С.В. Позіховська, Луцьк 2005; Стародруки Речі Посполитоі XVII-XVIII cm.cm. у Волинських збірках. Каталог, уклад. С.В. Позіховська, О.Л. Позіховський, Луцьк 2006).

${ }^{62}$ Obliczenia na podstawie IP НБУВ, ф. I, № 4709.

${ }^{63}$ РГИА, ф. 824, оп. 2, д. 142, k. 613-615. 
nych bazyliańskich (oprócz Wilna) oficyn typograficznych ${ }^{64}$. Są to dane szacunkowe, gdyż opisy sumarycznych wykazów książek z bibliotek bazyliańskich odnotowanych w aktach wizytacyjnych są dalekie od precyzji. Tym niemniej pozwalają one chociażby na ustalenie dość szerokiego zakresu pochodzenia książek, jak i języka publikacji. Według katalogu biblioteki klasztoru barskiego 60\% stanowiły łacińskie księgi, 36\% - polonica, 4\% - ruskie i słowiańskie druki. Polskojęzycznych pozycji najwięcej znajdowało się w kolekcjach kaznodziejskiej literatury, dzieł ascetycznych, medytacji czy katechizmów ${ }^{65}$. Warto tu odnotować ogólny wzrost pozycji łacińskich i polskich w bibliotekach bazyliańskich w ciągu XVIII wieku. W wielu książnicach stanowiły one pod koniec stulecia już $70-80 \%$ zgromadzonych ksiąg ${ }^{66}$.

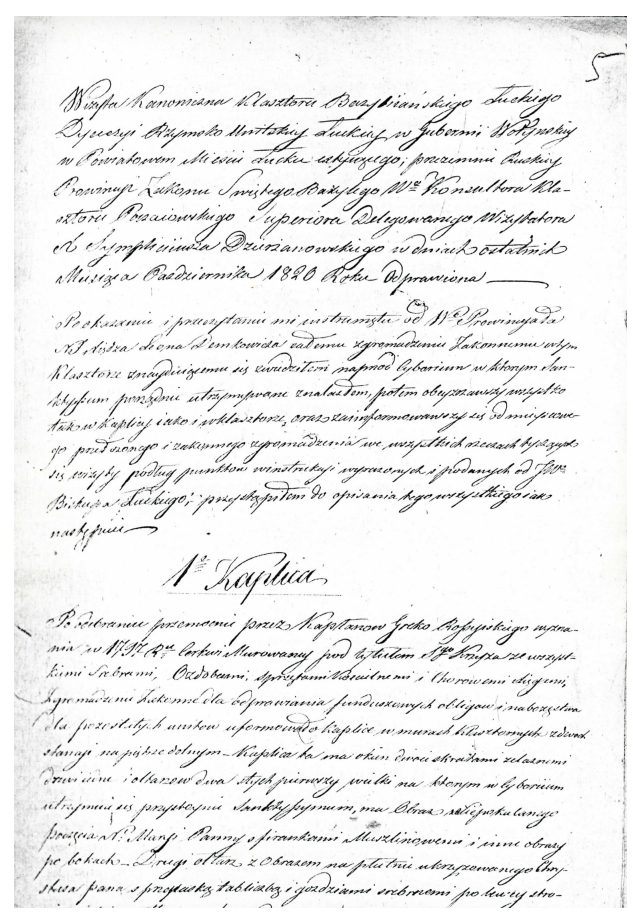

Il. 3. Strona tytułowa wizytacji klasztoru łuckiego w $1820 \mathrm{r}$. Źródło: РГИА, ф. 797, оп. 6, д. 23104, k. 5.

Analizując strukturę organizacyjną księgozbiorów w XIX wieku, można zauważyć, że książki porządkowano najczęściej w kilku kolekcjach tematycznych.

${ }^{64}$ Tamże, k. 7v-36v. Analiza księgozbioru: I. Wodzianowska, Monaster bazyliański w Barze w świetle wizytacji z lat 1820 i 1823, „Hereditas Monasteriorum”, 6 (2015) s. 291-316.

${ }^{65}$ Polskojęzyczne książki znajdowały się w tych działach obok mniej licznych ruskich, jak m.in.: Сьмя слова Божія (Poczajów 1772), kilkakrotnie wydawane w typografiach bazyliańskich Народовьщаніе, Собранїе Припадковъ, Богословіа нравоучителная.

${ }^{66}$ Por. I. Almes, „Latinitas polonice”: książka polska w monasterach bazyliańskich eparchii lwowskiej XVIII wieku, „Z Badań nad Książką i Księgozbiorami Historycznymi”, 11 (2017) s. 59-69. 
Najliczniejsze działy tworzyły księgi Pisma Św., ich tłumaczenia w różnych językach oraz księgi teologiczne (m.in. Dzieje Apostolskie, konkordancja biblijna, psałterze; kazusy, literatura religijno-polemiczna, podręczniki teologii), księgi kazań i homilii (dołączano katechizmy, rozmyślania na niedziele i święta, zbiory nauk religijnych). Pozycje te znajdowały się w każdej bibliotece klasztornej, bez względu na funkcję i liczebność placówki zakonnej. Kolejne działy to:

- prawny - prezentujący zarówno prawo świeckie, jak i kanoniczne (ustawy i reguły zakonne, uchwały synodów, bulle, druki dotyczące funkcjonowania zakonu bazylianów);

- historyczny, często łączony z geograficznym (kościelne i świeckie) ${ }^{67}$;

- ascetyczny (zbiory medytacji, literatura hagiograficzna, pieśni);

- filozoficzny, łączony z działami z zakresu matematyki, logiki, metafizyki;

- retoryczny i poetyki, gromadzący mowy i listy, literaturę poetów starożytnych, leksykony i słowniki. Rozbudowany był głównie w klasztorach prowadzących szkoły średnie, gdzie dzieła mówców i poetów, a także podręczniki wymowy stanowiły nawet $1 / 4$ ogółu zbioru bibliotecznego;

- pozycje, których treść uniemożliwiła zakwalifikowanie do powyższych działów, umieszczono w kolekcji pod tytułem - różne, „rozmaite”, varia. W zależności od miejsca przechowywania zaliczano do nich podręczniki gramatyki, słowniki, agendy, brewiarze, periodyki czy zbiory słowiańskich druków i pism (m.in. Łuck) lub „ksiąg spraw rożnych 29” (Włodzimierz); ,ksiąg rozmaitych, pism periodycznych 25" (Żydyczyn) czy metryki (Zimne).

${ }^{67}$ Szerzej literaturę historyczno-prawną w językach polskim i łacińskim gromadzoną przez bazylianów omawia M. Pidłypczak-Majerowicz: Literatura o państwie i prawie $w$ ksiegozbiorach klasztornych na ziemiach wschodnich Rzeczypospolitej w XVII i XVIII wieku, w: Klasztor w państwie średniowiecznym i nowożytnym, red. M. Derwich, A. Pobóg-Lenartowicz, Wrocław 2005, s. 375-385. 


\begin{tabular}{|c|c|c|c|c|c|c|c|c|c|c|c|c|c|}
\hline 离 & $a$ & $\Xi$ & $\triangleright$ & Jे & $\stackrel{\infty}{m}$ & 1 & 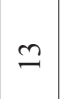 & $\hat{n}$ & 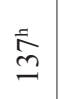 & $\infty$ & $\stackrel{N}{\Xi}$ & $\stackrel{\infty}{\sim}$ & F \\
\hline 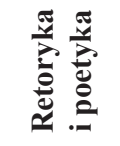 & $\infty$ & 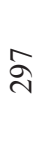 & 1 & $\vec{\sim}$ & 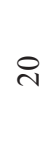 & $\approx$ & $r$ & $\mathfrak{J}^{f}$ & $\underset{+}{\infty}$ & I & $\stackrel{\sim}{\stackrel{F}{m}}$ & ঙे & $\Xi$ \\
\hline 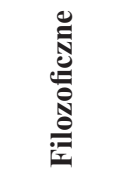 & $r$ & $\stackrel{\sim}{\underset{N}{N}}$ & 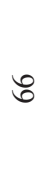 & $r$ & $\infty$ & $a$ & $\nabla$ & $\vec{n}$ & 1 & $\hat{n}$ & $\stackrel{?}{ \pm}$ & రి & I \\
\hline 芯 & 0 & & $\stackrel{\mathcal{F}}{+}$ & $\hat{\circ}$ & $n$ & 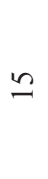 & లి & I & $\stackrel{\cong}{I}$ & $\hat{n}$ & 1 & 으 & ల) \\
\hline 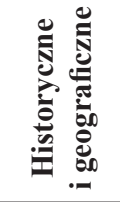 & in & 3 & $=$ & $\widehat{\sim}$ & ㄱ. & ป & $\stackrel{m}{=}$ & $\stackrel{2}{f}$ & ô & N & $\stackrel{\stackrel{\sim}{\sim}}{\sim}$ & $\vec{\sim}$ & 1 \\
\hline : & $\nabla$ & $\widetilde{\sigma}$ & \pm & $\stackrel{0}{0}$ & $\stackrel{0}{-}$ & $\cong$ & I & రి & $n$ & $\infty$ & $\stackrel{\infty}{\sim}$ & $\stackrel{m}{ }$ & $m$ \\
\hline 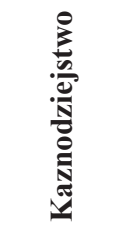 & m & $\ddot{\vartheta}$ & $\cong$ & 우 & $a$ & $\stackrel{0}{ }$ & $\stackrel{\sim}{\sim}$ & \pm & ิㅡ & $\stackrel{+}{m}$ & $\stackrel{\stackrel{+}{\sim}}{ }$ & $\approx$ & ले \\
\hline 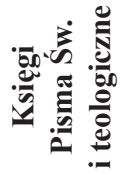 & $N$ & 于 & $\stackrel{\sim}{\forall}$ & $\hat{n}$ & 으 & ले & $\stackrel{\sim}{2}$ & 온 & $\stackrel{\infty}{ \pm}$ & in & 6) & $\approx$ & $a$ \\
\hline 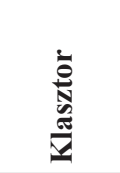 & - & ض̈ & $\frac{n}{\frac{n}{0}}$ & 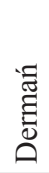 & $\begin{array}{l}\text { N. } \\
\text { ह } \\
0 \\
0 \\
0 \\
0 \\
0\end{array}$ & 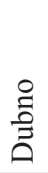 & $\begin{array}{l}\mathbb{N} \\
0 \\
N \\
0 \\
0 \\
\text { İ }\end{array}$ & 愨 & 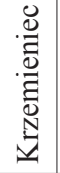 & 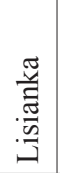 & $\begin{array}{l}\overline{\tilde{\Xi}} \\
\stackrel{0}{\Xi}\end{array}$ & لِ & $\frac{8}{0}$ \\
\hline
\end{tabular}

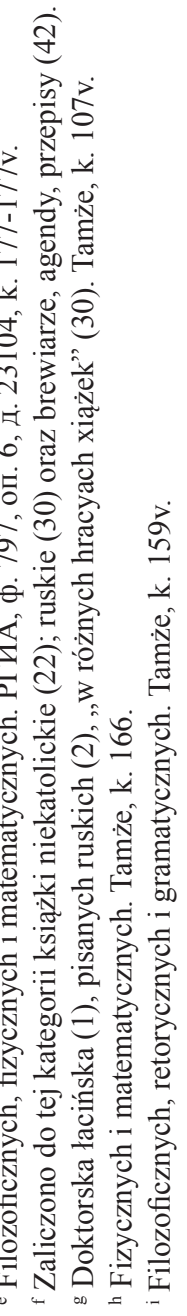




\begin{tabular}{|c|c|c|c|c|c|c|c|c|c|c|c|c|}
\hline$a$ & $a$ & - & $\begin{array}{l}\infty \\
\stackrel{\infty}{+}\end{array}$ & $ㅇ$ & in & ఫે & 1 & 1 & $\stackrel{\text { Ĭ }}{\stackrel{I}{ \pm}}$ & in & $\approx$ & $\Xi$ \\
\hline$\infty$ & 1 & $\stackrel{\circ}{\sim}$ & I & $\stackrel{\bullet}{\sim}$ & 1 & ते & - & 1 & $\stackrel{\Re}{\beth}$ & q & 6 & f \\
\hline$r$ & $\infty$ & $\infty$ & 1 & $\simeq$ & 1 & 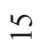 & 1 & $N$ & $\mathbb{N}$ & F & in & 우 \\
\hline 0 & $\stackrel{\sim}{\sim}$ & $\tilde{\lambda}$ & 1 & in & $\tilde{\curvearrowright}$ & $\infty$ & $\sim$ & 9 & $n$ & $\underset{T}{\mathbb{2}}$ & 인 & $\nabla$ \\
\hline in & $\infty$ & $r$ & $\hat{a}$ & $\cong$ & $\infty$ & $a$ & $\sim$ & $\sim$ & $\overline{0}$ & ஓ & $\infty$ & ミ \\
\hline$\nabla$ & $\underline{\ddots}$ & $=$ & 1 & $=$ & I & $\stackrel{\bullet}{v}$ & 1 & 1 & $\stackrel{ \pm}{\sim}$ & $\vec{\infty}$ & 1 & 过 \\
\hline$m$ & $\infty$ & 요 & ले & $\widetilde{N}$ & F & 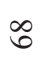 & $\stackrel{\Delta}{\sim}$ & 으 & $\cong$ & $\stackrel{\infty}{+}$ & ㄱ & $\infty$ \\
\hline$N$ & in & $n$ & $\sqrt{n}$ & $\stackrel{n}{2}$ & 2 & $\widehat{\sigma}$ & $N$ & 0 & $\stackrel{\Xi}{\Xi}$ & $\widehat{\beth}$ & $a$ & $\stackrel{\vec{m}}{\sim}$ \\
\hline- & 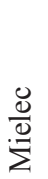 & 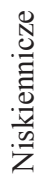 & $\overbrace{0}^{0}$ & $\begin{array}{l}\frac{0}{0} \\
\frac{0}{0} \\
\frac{0}{0} \\
0\end{array}$ & 离 & $\begin{array}{l}\stackrel{2}{0} \\
\text { 胥 } \\
\qquad\end{array}$ & $\underset{\Xi}{\Xi}$ & $\begin{array}{l}\text { ते } \\
\text { du } \\
\overrightarrow{3}\end{array}$ & 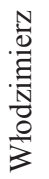 & 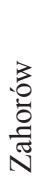 & $\stackrel{\Xi}{\Xi}$ & 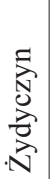 \\
\hline
\end{tabular}

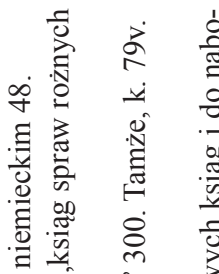

हैं⿰彳

$\begin{array}{lll}3 & 0 \\ 3 & 0 & 0 \\ 3 & 0 & 0 \\ 3 & 0 & 0\end{array}$

苞苛 3 a

घ ⿱ㅓㅁ

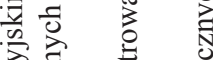

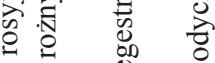

हี 禀

임

हू है है

㐘

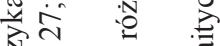

동 픙

$3 \frac{\pi}{2} \quad \frac{\pi}{\pi}$

总 吾

预 专 曹

ते.त्र

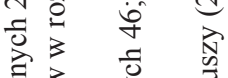

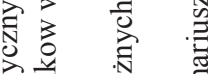

突 瓷

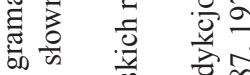

in $\ddot{\infty}$ 音

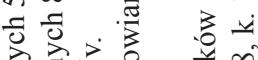

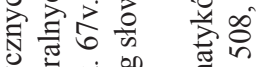

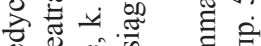

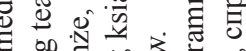
है

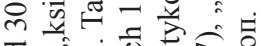

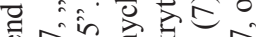

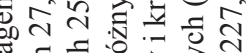

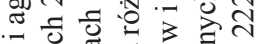
茫 엉

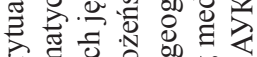

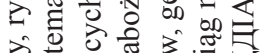

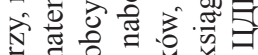

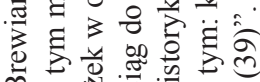

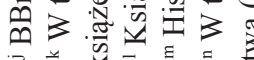
वे 
Przedstawiony podział tematyczny różnił się w poszczególnych monasterach, w których łączono lub wyodrębniano nowe kolekcje ${ }^{68}$. W Żydyczynie zgromadzono wspólnie ,historyków, geografów i krytyków”, a księgi „kaznodziejskie i ascetyczne" w monasterach w Barze, Humaniu, Lubarze. W klasztorach prowadzących szkoły zazwyczaj wyróżniano też słowniki i gramatyki, jak w Barze, Hoszczy, Humaniu, Mielcach, Tryhorach, Żydyczynie (,grammatyków i dykcjonariuszy”). W Dermaniu zaznaczono kolekcję „ksiąg niekatolickich”, bez rozróżnienia tematycznego, a w Poczajowie „zakazanych”. Najbardziej rozbudowany tematycznie księgozbiór zgromadzono w Humaniu, dzieląc go na 20 działów. Utworzono tu m.in. naukę języków obcych; arytmetykę, geometrię, astronomię, architekturę, wojskowość; fizykę, chemię, zoologię, botanikę i mineralogię; umiejętności lekarskie; historię powszechną, heraldykę, genealogię, mitologię i biografię; geografię, statystykę i opisy podróży ${ }^{69}$. Nie wyodrębniano rękopiśmiennych ksiąg, stąd też biblioteki bazyliańskie zawierały zarówno manuskrypty, jak i druki.

Akta wizytacyjne odnotowywały dwa księgozbiory - ksiąg chórowych i cerkiewnych oraz biblioteki klasztornej (Dubno, Poczajów, Poddębce, Tumin i in.). Tylko w kilku klasztorach nie zastosowano tego podziału - Dermań, Malejowce, Strakłów. Zbiory ksiąg cerkiewnych, liturgicznych lub - jak określano je najczęściej w protokołach wizytacyjnych - ,zakrystyjne i chórowe” (Bar, Dubno, Hoszcza, Humań, Kaniów, Lisianka, Werchy, Zahorów), „chórowe” (Białystok, Lubar, Łuck), „cerkiewne” (Dorohobuż, Krzemieniec), „,erkiewne i chórowe” (Mielec, Poczajów, Poddębce) przechowywano w kaplicy klasztornej bądź w zakrystii. Były to w większości ewangeliarze, psałterze, apostoły, czasosłowy, oktoichy, triody, służebniki, trebniki, mineje oraz irmołoje. Spisywane były odpowiednio po innym sprzęcie w zakrystii jak relikwiarze, lichtarze, chorągwie czy krzyże. Należy także zaznaczyć, że ewangelie oprawne w srebro wpisywano również do sreber klasztornych (np. Dermań, Mielec, Zahorów i in).

W miejscowościach, w których w latach 1795-1798 odebrano cerkwie klasztorne, utracono wraz z budynkami także większość ksiąg chórowych lub liturgicznych. W monasterze w Puhynkach pozostało wówczas tylko $14 \mathrm{ksiąg}^{70}$. Natomiast w pozostałych klasztorach liczba ksiąg wahała się od 24 do 168 (por. tabela 3).

Tabela 3. Księgi chórowe w klasztorach (1820-1824)

\begin{tabular}{|c|c|c|}
\hline Lp. & Miejscowość & Liczba ksiąg \\
\hline $\mathbf{1}$ & $\mathbf{2}$ & $\mathbf{3}$ \\
\hline 1 & Bar & 54 \\
\hline 2 & Białystok & 65 \\
\hline 3 & Dorohobuż & 24 \\
\hline 4 & Dubno & 30 \\
\hline
\end{tabular}

${ }^{68}$ Por. podział tematyczny zasobów bialskiej biblioteki: Wereda, Biblioteka bazylianów $w$ Biatej Podlaskiej, s. 426.

${ }^{69}$ Por. katalog biblioteki zakonnej: РГИА, ф. 824, оп. 2, д. 142, k. 110-155.

${ }^{70}$ РГИА, ф. 797, оп. 6, д. 23104, k. 100v. 


\begin{tabular}{|c|c|c|}
\hline 1 & 2 & 3 \\
\hline 5 & Hoszcza & 37 \\
\hline 6 & Humań & 51 \\
\hline 7 & Kaniów & 46 \\
\hline 8 & Krzemieniec & 85 \\
\hline 9 & Lisianka & 48 \\
\hline 10 & Lubar & 58 \\
\hline 11 & Łuck & 19 \\
\hline 12 & Mielec & $76^{\circ}$ \\
\hline 13 & Milcza & 19 \\
\hline 14 & Owrucz & 46 \\
\hline 15 & Poczajów & 168 \\
\hline 16 & Puhynki & 14 \\
\hline 17 & Tryhory & 87 \\
\hline 18 & Tumin & $24(1818)$ \\
\hline 19 & Werchy & 44 \\
\hline 20 & Włodzimierz & 52 \\
\hline 21 & Zahorów & 77 \\
\hline 22 & Zimne & 28 \\
\hline 23 & Żydyczyn & 39 \\
\hline
\end{tabular}

Źródło: ЦДІАУК, ф. 2227, оп. 1, спр. 508; РГИА, ф. 797, оп. 6, д. 23104; ф. 824, оп. 2 , д. 142; ІР НБУВ, ф. 231, № 152; ф. II, № 3345; 3349.

Wizytacje bazyliańskich wspólnot obok zbiorów bibliotecznych odnotowywały przechowywaną dokumentację monasterów. Na zbiory archiwalne w niektórych klasztorach przeznaczano osobne sale (np. w Zahorowie i Owruczu), w których „,dobrym i należytym porządku [archiwum było] ułożone" "71, rzadziej umieszczając je w bibliotekach (np. w Krzemieńcu). Zazwyczaj jednak, jak w Poddębcach, dokumentacja archiwalna złożona była w celi superiora „w osobnym na to kuferku" ${ }^{\prime 2}$. Podobnie w Tuminie przechowywano dokumenty w zamykanej na klucz szafie W celi przełożonego ${ }^{73}$, a w Barze ,w celi przełożeńskiey znajdowało się Bióro z 3a szufladami [przeznaczone] na Archiwum" 74 .

W innych klasztorach archiwalia były rozproszone. Przykładowo dokumenty łuckich bazylianów znajdowały się „po części w celi superiorskiey w skrzyni

o W tym 20 rękopiśmiennych ruskich, ułożonych w bibliotece (m.in. pomianyk, tołkowanie, służebniki czy statut litewski oraz opisanie różnych kamieni, drzew i zwierząt). РГИА, ф. 797, оп. 6, д. 23104, k. $85 \mathrm{v}-86$.

${ }^{71}$ Tamże, k. 78b, $147 \mathrm{v}$.

${ }^{72}$ ЦДІАУК, ф. 2227, оп. 1, спр. 508, k. 18.

${ }^{73}$ РГИА, ф. 797, оп. 6, д. 23104, k. 38v.

${ }^{74}$ Tamże, k. 178. 
osobney zamkniętey”, większa część zaś prawdopodobnie w skarbcu klasztornym $^{75}$. W Żydyczynie przechowywano dokumenty początkowo w skarbcu ${ }^{76}$, a następnie w pomieszczeniu bibliotecznym, w szafie ,na to sporządzoney”, podzielonej na 185 przegródek. Ułożone zaś zostało „,przez oznaczonego z prowincji zakonnika Xa Atanazego Kożuchowskiego", który sporządził także w 1789 r. sumariusz ${ }^{77}$. W części akt wizytacyjnych nie zanotowano miejsca przechowywania dokumentów, jak w Dubnie czy Włodzimierzu. Zaznaczyć natomiast należy, że wizytator wskazał, iż wspomniane wspólnoty posiadały archiwalia. Dokumentacją archiwalną najczęściej zarządzał przełożony klasztoru. Pośród 27 wizytowanych monasterów tylko w Owruczu odnotowano oficjalistę - osobę świecką, która opiekowała się dokumentacją klasztorną. Cela przeznaczona dla archiwisty mieściła się $\mathrm{w}$ jednym ze skrzydeł owruckiego monasteru, łączona drzwiami $\mathrm{z}$ archiwum ${ }^{78}$.

Co zatem zawierały archiwa klasztorne? W Poddębcach

oprócz funduszu pierwiastkowego iak się wyraziło w originale znayduiącego się są i inne dokumenta iako to zapisy na summy i skrypta temu klasztorowi służące iako prawno possesya summy czyniono ${ }^{79}$.

W Żydyczynie ,prawne dokumenta, processa, dekreta y różne transakcye" ${ }^{\text {. }}$. W kolejnych wizytacjach informacje uzupełniono o brak funduszu opackiego, a do opisu archiwaliów dodano

listy Królów Pol[skich] w Interessie klasztoru tego do różnych pisane, przywileia tychże na jarmark w Żydyczynie iako to: Zygmunta, Władysława IV, Augusta III. Dokumenta na ograniczenie dóbr opactwa żydyczyńskiego od różnych sąsiaduiących w wielkiey liczbie $\mathrm{i}$ inne papiery ${ }^{81}$.

W późniejszym protokole wizytacji (z 1820 r.) zaznaczono, że dokumenty nie były ułożone według inwentarza, a klasztor posiadał ponadto cztery mapy rozgraniczające jego ziemie z „ościennemi obywatelskiemi” ${ }^{\text {2. }}$. W Krzemieńcu archiwum zawierało dokumenty

summ Kapitalnych, skryptów, zapisów, Assekuracyi i Ugód iako też innych Tranzakcyi, Applikacyi, Processów, Dekretów w różnych Subseliach i Sądach następionych, lub też polubownie poczynionych ${ }^{83}$.

Czyli za każdym razem wizytator w bardziej lub mniej lakoniczny sposób odnotowywał dokumenty zabezpieczające majątek klasztorny, czyli zapisy różnych osób na rzecz wspólnot zakonnych, ich fundusze, przywileje, dekrety władz, akta procesowe. Wszystkie protokoły wizytacyjne wskazują na posiadanie tego rodzaju do-

\footnotetext{
${ }^{75}$ Archiwum nie posiadało także spisanego sumariusza. РГИА, ф. 823, оп. 3, д. 1282, k. 7v.

${ }^{76}$ ЦДІАУК, ф. 2227, оп. 1, спр. 508, k. 160.

${ }^{77}$ Tamże, k. $182 \mathrm{v}$.

${ }^{78}$ РГИА, ф. 797, оп. 6, д. 23104, k. 140.

${ }^{79}$ ЦДІАУК, ф. 2227, оп. 1, спр. 508, k. 27.

${ }^{80}$ Tamże, k. 168.

${ }^{81}$ Tamże, k. $182 \mathrm{v}$.

${ }^{82}$ РГИА, ф. 797, оп. 6, д. 23104, k. 33 v.

${ }^{83}$ Tamże, k. 62.
} 
kumentacji lub notują zawartość archiwum jak w klasztorach w Werchach ${ }^{84}$, Dermaniu $^{85}$, Malejowcach, Tuminie ${ }^{86}$. Wizytator zalecał natomiast spisanie sumariusza w monasterach, w których ich nie było (np. w Dermaniu).

Archiwum klasztorne nie zawsze przechowywało oryginały dokumentów. Przekazywano oryginały do archiwum prowincjonalnego, zachowując odpisy, a po pożarach próbowano odtworzyć. W Tuminie oryginalne papiery funduszu spłonęły wraz z biblioteką w czasie pożaru klasztoru. Odtworzono więc zawartość zbiorów, ale bez map rozgraniczeń majątków ${ }^{87}$. W Puhynkach zapisy funduszowe zostały przekopiowane, a „oryginalne oddane do Archiwum Prowincyonalnego" 88 . Wizytatorzy zaznaczali również braki pewnych dokumentów, jak np. w przypadku poświęcenia cerkwi lub klasztoru w Mielcu ${ }^{89}$.

Podsumowując, należy stwierdzić, że bazylianie przywiązywali dużą wagę do gromadzenia ksiąg. Doceniali ich rolę w kształceniu młodzieży oraz pracy duszpasterskiej i kaznodziejskiej. W ich księgozbiorach zgromadzono

w zasadzie wszystkie rodzaje ksiąg. Wiele bibliotek miało w swoich zbiorach bezcenne rękopiśmienne kodeksy słowiańskie i greckie, a także wielokrotnie przepisywane rzadkie drukowane księgi ${ }^{90}$.

Zadziwia zarówno zakres językowy, gdzie obok ksiąg ruskich, łaciny i poloniców, gromadzono pozycje w języku włoskim, niemieckim, francuskim, greckim, arabskim czy hebrajskim, jak i geografia prezentowanych oficyn wydawniczych (ponad 60). Wielkość zbiorów bibliotecznych najczęściej zaś zależała od uposażenia i funkcji klasztoru, a także wypadków losowych. W kilku klasztorach bowiem utracono księgozbiory w wyniku pożarów (Tumin, Dubno, Owrucz) lub odebrania przez duchownych prawosławnych (Hoszcza, Milcza).

Najliczniejsze księgozbiory posiadały ośrodki prowadzące szkoły średnie i zakonne, gdzie zgromadzono od tysiąca do trzech tysięcy woluminów, jak np. Bar (1711), Krzemieniec (2220), Lubar (1401), Humań (2953), Poczajów (2507) ${ }^{91}$. Wi-

${ }^{84}$, „(...) dokumenta prawne temu klasztorowi służące należytem porządku między innemi znayduię się w niem: 1. Fundusz originalny 1709 roku dnia 7 8bra przez W. Stefana Piotra Rzeczytcy i Doroty Skoropatnickich Rzeczyckich (...) zp 1800 (...) 2. Zapis W. Doroty Rzeczyckiey po W. Stefanie Rzeczyckim pozostałey Małżonki wdowey w roku 1716 dnia 3 Stycznia na Summe zp 14000 (...) Zawiera także wspomniane Archiwum inne dokumenta prawne, listy, protestacye, [k. 97v] i różne trakzakcyię w liczbie 33”. РГИА, ф. 797, оп. 6, д. 23104, k. 97-97 v.

85 „Ru 1597 dnia 24 maja - fundusza od JO Xięcia Konstantego Konstantynowicza Ostrogskiego; Ru 1609 dnia 27 listopada - potwierdzenie od JO Xięcia Janusza Ostrogskiego; Ru 1612 dnia 8 październik list od tegoż Xięcia anusza strogskiego kasztelana krakowskiego, zakazuiący Poddannych Monasterskich do żadnych robot Skarbowych odrywać (...) są i inne starożytne dokumenta, iako to: działy między Xiążentami, manifesta tak z strony klasztoru iako i z strony xiążąt (...)" РГИА, ф. 797, оп. 6, д. 23104, k. 266v-267.

${ }^{86}$ ЦДІАУК, ф. 2227, оп. 1, спр. 508, k. 220v.

${ }^{87}$ Tamże.

${ }^{88}$ Tamże, k. $102 \mathrm{v}$.

${ }^{89}$ РГИА, ф. 797, оп. 6, д. 23104, k. 84.

${ }^{90}$ Pidłypczak-Majerowicz, Bazylianie w Koronie i na Litwie, s. 154.

${ }^{91}$ M. Pidłypczak-Majerowicz, przytaczając w tabeli zbiorczej informacje o liczebności księgozbiorów zakonnych, podaje, że m.in. w Humaniu i Lubarze znajdowało się ok. 10-17 tys. wolumi- 
zytacje przede wszystkim pozwalają na ustalenie liczebności bibliotek bazyliańskich, a akta ostatniej (1823-1824) także na analizę zawartości bibliotek szkolnych i zakonnych oraz wyposażenia gabinetów.

Nawet nieliczne ubogie monastery bazyliańskie, z 3-4 zakonnikami, były ośrodkami edukacyjnymi wśród miejscowej ludności. Wszystkie bowiem klasztory, nawet gdy w zapisach funduszowych nie przewidywano działalności edukacyjnej, kształciły na własny koszt młodzież, najczęściej wywodzącej się z ubogiej szlachty. W wizytacjach stale pojawia się zapis o kilku osobach „na wikcie klasztornym" ${ }^{92}$. Czasami opłatą za naukę była pomoc w gospodarstwie. W Tuminie, jak odnotował wizytator w 1820 r., było „kilku sierot ubogich szlachty przy usłudzę, którym daie się czytanie, pisanie, nauka chrzescijańska i arytmetyka"93. Program mógł być rozbudowywany w zależności od poziomu wykształcenia samych zakonników. W Krzemieńcu zorganizowano szkołę dla dzieci obojga płci, gdzie oprócz nauki arytmetyki, czytania oraz pisania w dwóch językach - polskim i rosyjskim, uczono także podstaw łaciny.

Tragiczne losy zakonu bazyliańskiego, całkowicie zlikwidowanego na tym obszarze w 1839 r., podzieliły zbiory biblioteczne i archiwalne ${ }^{94}$. Po likwidacji klasztorów bazyliańskich ich majątek przejmowały monastery prawosławne. J. Giżycki pisze o bogatym archiwum oraz bibliotece klasztornej w Tryhorach, gromadzacych materiały skasowanych monasterów bazyliańskich m.in. w Kaniowie, Humaniu, Białołówce ${ }^{95}$, zbiory, które następnie stały się podstawą do utworzenia w $1893 \mathrm{r}$. Wołyńskiego Muzeum Prawosławnego ${ }^{96}$. Księgozbiory likwidowanych pomiędzy 1822 a 1832 r. wspólnot bazyliańskich początkowo przekazywano innym klasztorom bazyliańskim. Przykładowo, rozkazano, by barski księgozbiór po kasacie zarówno klasztoru, jak i szkoły, „oddać Byteńskiemu klasztorowi”97, a gdy ten rów-

nów. Por. Biblioteki i bibliotekoznawstwo zakonne na wschodnich ziemiach Rzeczypospolitej w XVII-XVIII wieku, Wrocław 1996, s. 173.

${ }^{92}$ Np. w Zahorowie. РГИА, ф. 797, оп. 6, д. 23104, k. 80.

${ }_{93}^{9}$ РГИА, ф. 797, оп. 6, д. 23104, k. 40 v.

${ }^{94}$ Por. Pidłypczak-Majerowicz, Książka i biblioteka bazyliańska w XVII-XVIII w. oraz wpływ kasat, s. 94-95.

${ }^{95}$ J.M. Giżycki, Bazylianie we Włodzimierzu i Tryhórach, Kraków 1912, s. 165. Wykaz cenniejszych książek: s. 166.

${ }^{96} \mathrm{~W}$ niewielu zbiorach bazyliańskich zachowały się listy przekazywanych książek do innych instytucji po zamknięciu klasztorów, które pozwalają przynajmniej częściowo na ustalenie liczby instytucji, którym oddawano księgozbiór. Po likwidacji owruckiej wspólnoty bazyliańskiej 241 pozycji oraz część wyposażenia gabinetów wybranych przez nauczyciela liceum wołyńskiego Aleksandra Sawickiego przeznaczono do tworzonej szkoły w Owruczu, ostatecznie zaś oddano do łuckiej. Resztę biblioteki, w tym większość polskojęzycznego zbioru oraz pozostałości fizyczno-matematycznych gabinetów, planowano przekazać trynitarzom w Teofilpolu (ЦДІАУК, ф. 2162, оп. 3, спр. 9, katalog zabranych ksiąg: k. 11-22v). Bogate zbiory monasteru tryhorskiego rozproszono, przekazując cenniejsze egzemplarze do nowoutworzonego przy Wołyńskim Cerkiewno-Archeologicznym Towarzystwie muzeum w Żytomierzu (ЦДІАУК, ф. 2094, оп. 2, спр. 1121, w latach 1893-1894), Kijowskiej Akademii Duchownej (w latach 1883-1892, tamże, спр. 915), różnym szkołom (w latach 1833-1838; tamże, спр. 338) czy prawosławnemu seminarium wołyńskiemu (tamże, спр. 1243).

${ }^{97}$ РГИА, ф. 824, оп. 1/II, д. 4 (1837), k. 33. 
nież został zamknięty, zbiory przejęli prawosławni mnisi. Po kasacie klasztoru w Dermaniu „,enniejsze dokumenty po roku 1822 zostały wywiezione do Moskwy, Petersburga i innych miast Rosji" "98. Według E. Chwalewika ten monaster posiadał ,sporo rzadkich starych druków polskich i rękopisów, niektóre prawdopodobnie jeszcze z daru ks. Konstantego Ostrogskiego" "99. Akta wizytacyjne pozwalają na ustalenie liczebności tych zbiorów i ich ogólną charakterystykę na kilka lat przed całkowitą likwidacją klasztorów (1832-1839).

\section{REFERENCES / BIBLIOGRAFIA}

\section{Źródła}

Rossijskij Gosudarstvennyj Istoričeskij Arhiv (Российский Государственный Исторический Архив), f. 797, ор. 6, d. 22176, 23104; f. 823, ор. 3, d. 1282; f. 824, ор. $1 /$ II, d. 4; op. 2, d. 142.

Central'nij deržavnij ìstoričnij arhiv u Kiêvi (Центральний державний історичний архів у Києві), f. 2070, op. 1, spr. 104; f. 2094, ор. 2, spr. 161, 338, 252, 915, 1121, 1243; f. 2162 , op. 3, spr. 9; f. 2227 , op. 1, spr. 508.

Institut rukopisu Nacional'noji biblioteki Ukraini im. V. I. Vernads'kogo (Інститут рукопису Національної бібліотеки України ім. В. І. Вернадського), f. 231, № 152; f. I, № 4709; f. II, № 3345, 3349 .

Deržavnij arhiv Žitomirs'koji oblasti (Державний архів Житомирської області), f. 90, op. 2, spr. 9.

\section{Opracowania}

Almes Iwan, Księgi cyrylickie w bibliotekach monasterów bazyliańskich eparchii lwowskiej XVIII w., „Latopisy Akademii Supraskiej”, 7 (2016) s. 209-216.

Almes Iwan, „Latinitas polonice”: książka polska w monasterach bazyliańskich eparchii lwowskiej XVIII wieku, „Z Badań nad Książką i Księgozbiorami Historycznymi”, 11 (2017) s. 59-69.

Al'mes Ivan, Latino- $i$ pol's'komovni starodruki monastirs'kogo pohodžennâ u fondah Deržavnogo arhivu Ternopil's'koji oblasti, ,Arhivi Ukrajini”, (2015) № 4 (297), s. 116126.

Chwalewik Edward, Zbiory polskie, archiwa, bibljoteki, gabinety, galerje, muzea i inne zbiory pamiątek przeszłości w ojczyźnie i na obczyźnie w porzadku alfabetycznym wedtug miejscowości ułożone, t. 1, Warszawa 1927.

Dobrotvorskij Amvrosij, Zagorovskij monastyr', ego biblioteka i sohranivšijsâ v nej zapadno-russkij literaturnij pamâtnik XVII stoletiâ, AJZZR, kn. 1, izd. 2, Kiev 1863, s. 1-17; kn. 2, izd. 2, s. 75-115; kn. 3, izd. 2, s. 165-196.

Getka Joanna, Polskojęzyczne druki bazyliańskie (XVIII wiek), Warszawa 2013.

Getka Joanna, U progu modernizacji. Ruskojęzyczne drukarstwo bazyliańskie XVIII wie$k u$, Warszawa-Lublin 2019.

${ }^{98}$ Pawluczuk, Monaster Świętej Trójcy w Dermaniu w II Rzeczypospolitej, s. 500.

${ }^{99}$ E. Chwalewik, Zbiory polskie, archiwa, biblioteki, gabinety, galerie, muzea i inne zbiory pamiątek przeszłości w ojczyźnie i na obczyźnie, Warszawa 1927, t. 1, s. 63. 
Giżycki Jan Marek, Spis klasztorów unickich bazylianów w województwie wołyńskiem, Kraków 1905.

Giżycki Jan Marek, Bazylianie we Włodzimierzu i Tryhorach, Kraków 1912.

Katalog vidan' Počajivs'kogo ta Univs'kogo monastiriv XVIII-XX st. z kolekciji Muzêิu knigi i drukarstva Ukrajini, uporâd. V. G. Bočkovs'ka, L. V. Hauha, V. A. Adamovič, Kijiv 2008.

Lorens Beata, Bazylianie prowincji koronnej w latach 1743-1780, Rzeszów 2014.

Los' Valentina, Vasilians'ki biblioteki v svitli monastirs'kih inventariv Nacional'noji biblioteki Ukrajini im. V.I. Vernads'kogo (Pravoberežna Ukrajina XVIII-XIX st.), w: Między Rzymem a Nowosybirskiem. Księga jubileuszowa dedykowana ks. Marianowi Radwanowi SCJ, red. H. Łaszkiewicz, I. Wodzianowska, Lublin 2012, s. 605622.

Los' Valentina, Rukopisna spadŝina monastiriv Greko- ta Rimo-katolic'koji cerkov u fondah Institutu rukopisu Nacional'noji biblioteki Ukrajini imeni V. I. Vernads'kogo, „Hereditas Monasteriorum”, 6 (2015) s. 237-250.

Pawluczuk Urszula, Monaster Świętej Trójcy w Dermaniu w II Rzeczypospolitej, w: Między Odra a Uralem. Księga dedykowana Profesorowi Władysławowi A. Serczykowi, red. W. Wierzbieniec, Rzeszów 2010, s. 499-507.

Paszkiewicz Urszula, Cathalogus cathalogorum. Inwentarze i katalogi bibliotek z ziem wschodnich Rzeczypospolitej od XVI wieku do 1939 roku. Spis scalony, poprawiony i uzupetniony, t. 1-2, Warszawa 2015.

Petrov Nikolaj I., Opisanie rukopisnih sobranij, nahodâsihsâ v gorode Kieve, Moskva 1896.

Pidłypczak-Majerowicz Maria, Bazylianie w Koronie i na Litwie. Szkoły i książki w dziatalności zakonu, Warszawa 1986.

Pidłypczak-Majerowicz Maria, Biblioteki i bibliotekoznawstwo zakonne na wschodnich ziemiach Rzeczypospolitej w XVII-XVIII wieku, Wrocław 1996.

Pidłypczak-Majerowicz Maria, Ksiażka i biblioteka bazyliańska w XVII-XVIII w. oraz wptyw kasat na stan ich zachowania i opracowania, „Hereditas Monasteriorum”, 1 (2012) s. 85-97.

Pidłypczak-Majerowicz Maria, Literatura o państwie i prawie w księgozbiorach klasztornych na ziemiach wschodnich Rzeczypospolitej w XVII i XVIII wieku, w: Klasztor w państwie średniowiecznym i nowożytnym, red. M. Derwich, A. Pobóg-Lenartowicz, Wrocław 2005, s. 375-385.

Pidłypczak-Majerowicz Maria, Prywatne księgozbiory bazylianów prowincji koronnej zakonu na podstawie proweniencji wynotowanych z druków XVI-XVIII wieku w zbiorach Ossolineum. Zarys zagadnienia, „Z Badań nad Książką i Księgozbiorami Historycznymi", 10 (2016) s. 95-106.

Starodruki Reči Pospolitoji XVII-XVIII st.st. u zibrannâh Muzê̂ knigi ta drukarstva m. Ostroga ì Volins'kogo kraêznavčogo muzê̂. Katalog, uklad. O.L. Pozìhovs'kij, S.V. Pozihovs'ka, Luc'k 2005.

Starodruki Reči Pospolitoji XVII-XVIII st.st. u Volins'kih zbirkah. Katalog, uklad. S.V. Pozihovs'ka, O.L. Pozihovs'kij, Luc'k 2006.

Wereda Dorota, Biblioteka bazylianów w Biatej Podlaskiej, „Archiwa, Biblioteki i Muzea Kościelne", 112 (2019) s. 419-437.

Wodzianowska Irena, Etapy likwidacji wspólnot bazyliańskich w Imperium Rosyjskim na przykładzie Prawobrzeżnej Ukrainy, w: Kasaty klasztorów na obszarze dawnej Rzeczypospolitej Obojga Narodów i na Ślasku na tle procesów sekularyzacyjnych w Eu- 
ropie, red. M. Derwich, t. 1: Geneza. Kasaty na ziemiach zaborów austriackiego i rosyjskiego, Wrocław 2014, s. 271-286.

Wodzianowska Irena, Monaster bazyliański w Barze w świetle wizytacji z lat 1820 i 1823, „Hereditas Monasteriorum”, 6 (2015) s. 291-316.

\title{
THE CONDITION OF LIBRARIES AND ARCHIVAL COLLECTIONS OF BASILIAN MONASTERIES IN THE LIGHT OF THE VISITATION (1799-1824)
}

\begin{abstract}
The basic sources in the research on monastic libraries, apart from library catalogues, include visitation files, recording the numerical size of communities and the size of monastic book collections. The visiting inspectors recorded the number of volumes, contents, library rooms and the archival documentation of individual monastic institutions. The preserved visitations to Basilian monasteries allow for the analysis of 27 book collections in the Uniate Diocese of Lutsk during the first quarter of the 19th century. This documentation makes it possible to determine the number of collections, the pace of their increase, and their thematic scope. Several years later, after the dissolution of the Basilian Fathers, most of these libraries would be dispersed, a large part of the books donated to educational institutions, while more valuable items were transferred to museums and university libraries. Visitation files are therefore a valuable source for exploring the collections, the places where they were stored, as well as the contents of the monastic archives. Monastic libraries varied in size, organization, and substantive content. They served primarily as support in the pastoral and educational work of monks. Both theological works and fiction works, as well as Western European manuscripts and editions were collected in the monasteries. The range of Polish and foreign typographies testified to the high intellectual culture of the order. Even small communities scattered in rural centres offered the opportunity of contact with books and educating local youth. Undoubtedly, they formed the cultural landscape of these lands.
\end{abstract}

Keywords: libraries; visitation files; monastic archives; Basilian fathers; the Uniate Diocese of Lutsk; Greek Catholic Church 